Crime, Histoire \& Sociétés / Crime, History \& Societies

Vol. 21, n² | 2017

L'histoire de la criminalité et de la justice pénale : propositions de recherche pour le $21^{\mathrm{e}}$ siècle

\title{
Future Themes and Research Agendas on Crime and Police in Wartime
}

\section{Clive Emsley}

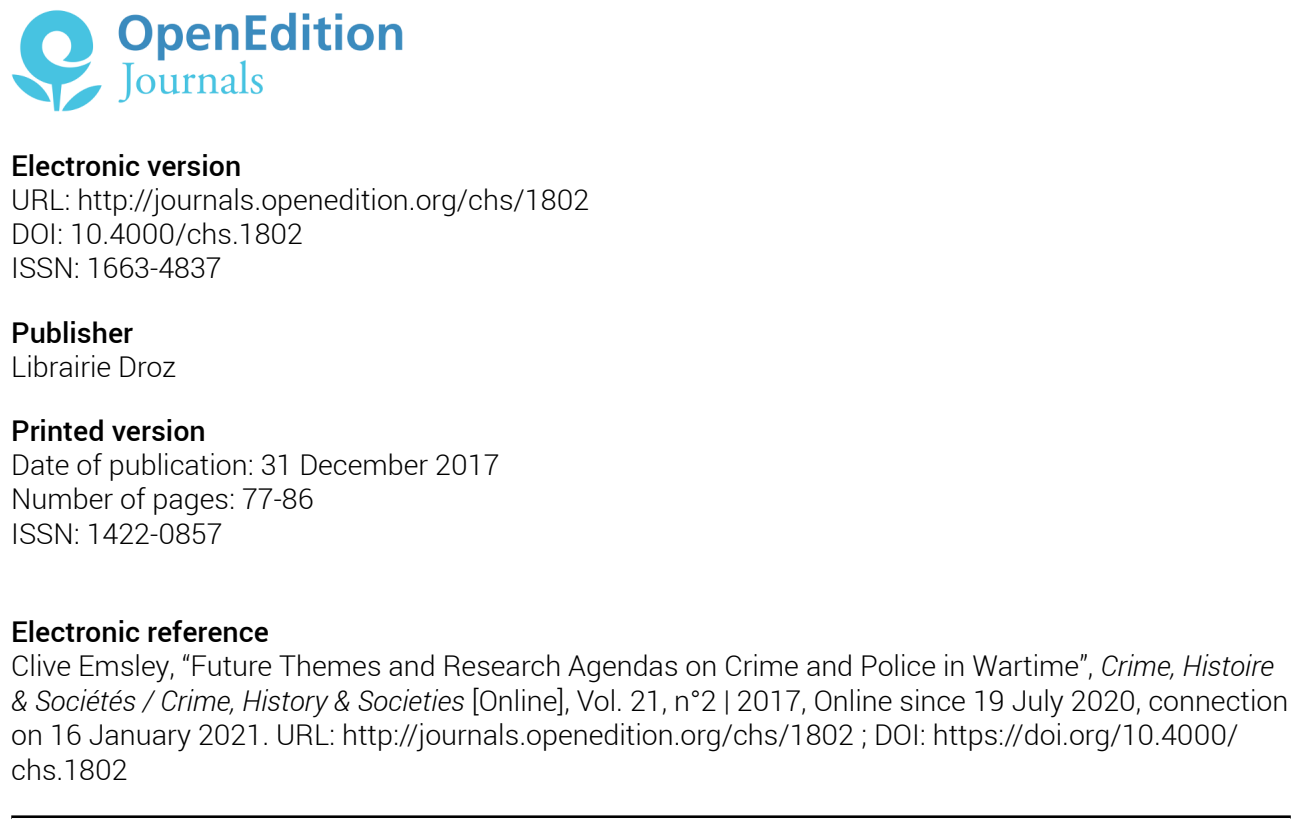

(C) Droz 


\title{
Migration as Crime, Migration and Crime
}

\author{
Margo De Koster, Herbert Reinke
}

$\mathrm{W}$ e are currently witnessing growing social tensions and intense debate concerning a putative "migration crisis", evidenced by a resurfacing of century-old fears of "unwanted newcomers" and increasing friction between the authorities and members of migrant and minority communities ${ }^{1}$. Social scientists often assume that such issues are of fairly recent advent. They suggest that, today, (im)migration controls result in an unprecedented criminalization of immigrants, and their increasing exposure to illegality, crime and punishment ${ }^{2}$. This article does not seek to dismiss these claims, but rather to frame the current issue of the "migration as/and crime"-complex by considering both the longer-term roots of the problem drawing on recent historical research, and more recent developments in the postSecond World War era, as documented by criminologists and sociologists.

The influx of foreign labour and so-called "guest workers" in the Fordist economies of Western Europe and America between the 1950s and 1970s heightened fears about criminal foreigners, and led to a wave of research about the criminal activities of these migrants ${ }^{3}$. The same happened during and after the fall of communist regimes in Central and Eastern Europe. However, the research undertaken in these two periods aimed at investigating the supposed criminality of migrants was largely unsuccessful, even when sophisticated conceptual tools were applied, such as culture/ conflict theory or the notion of anomie. By confronting the legacies of these former discourses with a number of core elements from current "crimmigration" debates, we aim to identify issues and questions that are either new and different today, or rather show remarkable continuity across time. As well as delineating topics for future historical research this essay also aims to contribute to the elaboration of conceptual and theoretical contexts helpful to current "crimmigration" debates.

\section{A LONGER HISTORY OF A VERY RECENT PAST}

On the first of May 1517, later to be labelled the "Evil May 1517", London was the scene of violent riots against Flemish, German and Italian merchants and craftsmen, who were accused of ruining the local economy and harassing women and girls. This incident sheds light on a complex cluster of elements that seem to be essential in the representation of "migration as/and crime" over the longue durée: foreigners are seen as damaging the local economy, described as cheats and criminals, and they are

Beier and Ocobock (2008); Berlière and Lévy (2011).

Melossi (2015).

Walter (1989).

Crime, Histoire \& Sociétés / Crime, History \& Societies 2017, vol. 21, n² 2, pp. 63-76. 
accused of threatening local gender norms. The rioting was amplified by xenophobic propaganda: the violence erupted after a local parish vicar issued this propaganda publically ${ }^{4}$. There are striking resemblances between these past events and the recent xenophobic propaganda against Mexicans, circulated during the campaign of the current United States president, Donald Trump. Also remarkable is the strong continuity in - or rather recurrence of - the accusations of danger, disorder and crime directed towards foreigners, strangers and migrants. After Evil May Day 1517, the King of England reacted severely: approximately 1,500 men were sentenced to death and executed, not necessarily as a punishment for persecuting the foreigners, but mainly as a measure intended to restore public order. Even this betrays similarities to current issues, since anti-Mexican migrant policies and discourses today do not aim at controlling the phenomenon, but rather to restore (the constitutional) order, as the president and other proponents of these policies have indicated.

Mainstream migration research tends to omit crime from its analyses ${ }^{5}$. Two recent encyclopedic reference works pay no explicit or very little attention to crime ${ }^{6}$. Historical research is less silent: an overview study is still lacking, but the available literature allows for cautious conclusions, stimulating a demand for further research. One such conclusion - as the example above also suggests - is that "crime" should not be defined strictly in legalistic terms, but rather be broadened to include the notions of threat, irregularity and disorder that have informed public and official fears and responses to immigration. The overall picture emerging from the available historical research is that these are all important and recurrent components of the "migration as/and crime"-complex, appearing in different periods and geographical locations. Recent studies have examined, for example, how fears about and riots against foreigners evolved in early-fifteenth-century London and in late-nineteenthcentury France; how threats were perceived to originate from the nineteenth-century vagrant paupers in many European countries; how young male foreign workers have been the subject of particular fears, with so-called rough Polish workers in the Ruhr before 1900 and young Italian guest workers after the Second World War being suspected of abusing young women in their respective host societies; and how the police and the courts in nineteenth and early twentieth century Europe have handled migrants and minorities ${ }^{7}$.

Historical research not only gives the impression that the circumstances which dictate the emergence of the "migration as/and crime"-complex have recurred across time and space, but also, because of the historical method of reconstructing the past from source material, alerts us to the necessity of adopting a constructivist approach in analyses of the close associations drawn between migration and crime. A major question for historical research is, inter alia, how definitions of threat or danger associated with the migrant, the stranger and the refugee evolve through time, and how they shape migration and security policies and police and criminal justice practices.

Ness (2013).

There are, of course, exceptions to this rule, such as Leerkes, Engbersen and Leun (2012).

Bade, Emmer, Lucassen and Oltmer (2011); Ness (2013).

Viet (2002); Dornel (2004); Deutsches Historisches Museum (2005). 


\section{THE MIGRANT AS CRIMINAL "OTHER": CRIMINALIZING NARRATIVES}

Recent decades have witnessed, across the world, the flourishing of a set of public narratives that link "alien" with "criminal Others" and that highlight the threat posed by irregular or clandestine migrants to domestic safety and public order $^{8}$. Criminologists and sociologists have increasingly been paying attention to the question how these official and public discourses on "crimmigrant bodies" are reflected in migration policies and in migrants" everyday life experiences". This figure of the migrant as "criminal Other" or the "criminal alien" has a very long history, as was already suggested in the previous section. Constructions of foreignness and alterity in relation to deviance and crime go back to the late Middle Ages at least ${ }^{10}$. In these remarkably enduring narratives that link irregular migrants to crime and disorder, two main problem figures appear: the stranger-outsider on the one hand, and the irregular migrant labourer on the other. Despite this continuity, the precise problem-definitions and social tensions behind both categories of criminal aliens have evolved over the past centuries as a result of increasing globalization of both migratory patterns (from regional to international to transnational) and the economy (changing demand for labour).

First, the non-belonging stranger evolved from a category that was mainly defined in terms of birth and local belonging (ius soli) in the early modern period to one that was increasingly defined in terms of nationality and citizenship from the nineteenth century onwards ${ }^{11}$. National vagrancy laws in various countries stated that vagrants-citizens were to be incarcerated and re-educated in state colonies, while foreign vagrants were to be expelled ${ }^{12}$. After new national vagrancy legislation was introduced in Belgium in 1891, a question about nationality was formally integrated in the interrogation protocol to be used by the police in cases of vagrancy. The distinction between state citizen and foreigner started to determine social reality: strangers became even stranger. All across Europe, nationality laws were rationalized: in France in 1889, in the Netherlands in 1892; Belgium in 1909 and the German Reich in 1913. At the same time, the state infrastructure and bureaucratic framework for identity and nationality verification was expanded considerably ${ }^{13}$.

During the twentieth century, notions of ethnic and religious difference came to occupy an increasingly central place. Stereotypical labelling of certain ethnic or religious minorities as criminal was of course nothing new: "ritual" murder as a typical crime for Jews to commit, the drunken and "filthy" catholic Irish, Latinos as drug-dealers and rapists, etc. ${ }^{14}$ What did change, however, is that after the Second World War, foreignness and alterity came to be defined almost exclusively in terms

\footnotetext{
According to Pratt and Valverde, as a result of increasingly demonising discourses about migrants from the 1990s onwards, even refugees have lost their status of "deserving victims" and have been ascribed that of "masters of confusion", to be suspected and monitored closely (Pratt and Valverde, 2002).

9 Aas (2011); Kubal (2014).

10 De Koster and Reinke (2016).

11 Snell (2006); Winter and Lambrecht (2013).

12 Lawrence (2011).

13 Noiriel (1991); Caestecker (2001); Caplan and Torpey (2001).

14 Emsley (2007).
} 
of ethnicity and religion. Changing migration patterns brought more long-distance migrants and greater cultural, ethnic and religious diversity to the Western world ${ }^{15}$. At the same time, decolonisation pressures meant that the European empires general sough to bolster their membership regimes, emphasizing the interconnectedness of the colony and the metropole and the equality of all inhabitants of the empire ${ }^{16}$. However, in some countries such as Belgium, but also in the United States, this "inclusive turn" remained limited. Migration regulations, visa obligations, citizenship criteria and integration opportunities did not change significantly and these countries thus continued a regime of ethnic segregation ${ }^{17}$. Moreover, even when legal changes were made, the incorporative rhetoric and stress on equality did not necessarily lead to inclusion in practice ${ }^{18}$.

During the past few decades, religion has joined ethnicity at the forefront of narratives about the "criminal alien": one could argue that the issue has undergone a "muslimization". The "Arab Other" has emerged as the pre-eminent "folk devil" of our time, functioning in the national imaginary to prop up the project of national belonging ${ }^{19}$. This process appears strangely familiar to the historian: Are we back in the early modern period, when central authorities were mostly concerned with regulating religious minorities, which occasionally led to forced expulsions - as in the case of Jews and Muslims in sixteenth-century Spain and Huguenots in late seventeenth-century France - or to more or less voluntary emigration, such as that of Protestants from the Southern Low Countries at the end of the sixteenth century?20

The second problem figure appearing in narratives about migrants as a "criminal Other" is the irregular migrant worker. Early modern local authorities were mainly concerned with the regulation of labour migration, because the economy and concerns about poor relief were key issues. This led to increasing monitoring and criminalisation of casual, irregular workers: labourers without permit, journeymen and the unemployed. The "worker book" or livret which detailed the places and dates of previous positions became a central control instrument from the eighteenth century onwards, together with vagrancy legislation, criminalising not only the inability to prove stable attachment to a local community and failure to register as required by law, but also the lack of a steady income ${ }^{21}$. The intensity of these controls fluctuated considerably, however: whatever location and time one picks in Europe and the United States, one will find a cyclical process of liberalisation and restriction, whereby short-term variations in the economic climate and the demand for labour had immediate repercussions on the parameters of migration control ${ }^{22}$. For example, as is the case with eastern European labour migrants today, migrants in Amsterdam between 1600 and 1800 were free to enter because the urban authorities considered a

\footnotetext{
15 Bowling and Phillips (2003).

16 Brubaker (1992).

17 Schepers (2014); Collomp (1996).

18 This has been highlighted as a fundamental paradox of the French Immigration Law of 1945, see for example Blanchard (2011).

19 Poynting, Noble, Tabar and Collins (2004).

20 For an overview, see Bade et al. (2011).

21 De Munck and Winter (2012); Lawrence (2011); Gaume (2017).

22 Dohse (1985); Collomp (1996); Trautmann (2002); Fahrmeier (2005).
} 
constant stream of immigrants necessary to satisfy the port city's massive demand for labour. During periods of economic downturn, providing immigrants with some poor relief was considered a necessary evil, yet their relief entitlements stood at a much more modest level than those of citizens or long-term residents ${ }^{23}$.

Today, the irregular migrant worker is once again perceived as a problem, but his/her status seems to have shifted from one requiring regulation to a deliberately maintained precarious and semi-legal status. Globalization and the expansion of the service industry have urged to recruit immigrants for the "3D Jobs" (Dirty, Demanding, Dangerous $)^{24}$. As a result, it has become an integral part of migration policies to keep newcomers in a situation of irregular or vulnerable employment (euphemistically named "fluid" or "flexible" positions), to afford them limited social protection and dispense primarily temporary residence permits (privileging circular to permanent migration). In contrast to the Fordist figure of the guest worker, it is no longer about getting them in a socially integrated yet inferior position. From now on, migrant workers may live within a state's borders while being kept at the margins of judicial and social institutions. As Nagels and Rea have recently put it: "la clandestinité peut devenir un statut social durable" ${ }^{25}$. Paradoxically, while employers in Europe and the United States are keen to hire them, illegal and irregular labour migrants are invariably demonised in official and public narratives ${ }^{26}$.

Despite the important shifts in migration patterns and policies discussed above, remarkable continuity can be detected in the framing of the "criminal alien" since the early modern period. We therefore believe that conceptual and theoretical addedvalue could be gained by looking at these narratives and frames as cyclical, rather than as "new". Behind the recurring "crimmigrant bodies" in the discourses, however, have been very different migrant populations across space and time, with a wide variety in origins, ethnicity, religion and cultural frameworks in general. Historical research should thus identify whether certain mobile individuals and groups have been more problematized and criminalized than others at certain moments in history and in certain regions, in order to deepen our understanding of the socio-political construction of migration as both threatening and frequently illegal ${ }^{27}$.

\section{CRIMMIGRATION: AN OLD NEW ISSUE?}

This third and final section engages in a dialogue with recent "crimmigration" studies in criminology. It focuses on four themes raised by historical studies we consider will be important and fruitful for future transdisciplinary research.

\footnotetext{
Lucassen (2012).

Castles (2002).

Nagels and Rea (2010, p.47).

Adam et al. (2002).

27 Huysmans (2006).
} 


\section{People moving out versus people moving in}

Current discussions of the "migration as/and crime"-complex are significantly biased towards migration as some sort of moving in. Moving out receives much less attention: attempts to criminalize people trying to move out and specific emigration regimes (penal laws to keep people from leaving the country, fortified border regimes) have inspired very little conceptual and theoretical reflection regarding the "migration as/ and crime"-complex. Research has pointed out, however, that during the early modern period, due to the prerequisites and the necessities of the mercantilist economic system, having a large population was considered of great economic value to a state. With the rise of capitalism and liberal free trade, and with the significant growth in migration flows that industrialization and urbanization brought about in the nineteenth century, it might be assumed that the need of keeping people from moving out gradually lost its significance.

However, the criminalization of illegal emigrants did re-emerge on a large scale with the establishment of communist regimes in Central and Eastern Europe after the Second World War. Communist authorities not only tried to retain their populations for ideological and political reasons, but the outward movement of citizens was also hampered due to their perceived role as productive factors in the socialist economies. Only those who could no longer contribute to the production process (such as retired women and men) were allowed to move away. These strategies of trying to keep people inside state borders were only partly successful. During the early modern period, keeping citizens from moving out was accompanied by active immigration policies, inviting highly specialized and skilled workers, often of foreign origin, into state territories. Authorities were thus forced to uphold a balance between criminalizing emigration and stimulating immigration at the same time ${ }^{28}$. In the former communist regimes in Central, Eastern and Southeastern Europe, on the contrary, such a balance was never part of the strategies developed. East Germany and Albania really only tried to keep people in, a policy which became successful only after the Berlin Wall had been built and the other borders of East Germany had been fortified. Such endeavours were strengthened by the issuing of the instruction to the East German border police to shoot people trying to get out - even if this proved fatal ${ }^{29}$.

\section{Bringing the local level back in}

Recent crimmigration studies focus on international migration and inter- and transnational legal frameworks, for evident reasons. Today, migration regulation is predominantly the result of decisions taken at inter-state and international level, through bilateral agreements with other states, international agreements (within the EU mostly), human rights conventions, and so on. In the early 2000s, for example, the decision to liberalize the migration of citizens from eastern European countries that had become EU members (including Poland, Hungary, Romania and Bulgaria) was taken by individual European states but within the framework of the EU. As a result of this decision, cities in these EU member states had to adopt the international agreement and national rules and had few instruments left to regulate the movements of these eastern European migrants. Yet urban centres remain the main places of

\footnotetext{
28 Bade (2011).

29 Marxen and Werle (2002).
} 
arrival, having to deal with social problems and tensions, such as illegal housing, violence and alcohol abuse. Although often temporary issues they are often socially significant and hard to solve ${ }^{30}$. Recent historical research suggests that the local level has indeed remained a crucial actor in migration control throughout the past centuries and that there are two main reasons why it is important to "bring the local back in".

First, there is the impact of local sensibilities and perceptions on definitions of the unwanted (versus deserving) newcomer. At the local level, one of the oldest fears about immigrants was that they would become dependent on local poor relief; this was crucial for the way migration policies were devised. In determining which newcomers were entitled to care, criteria of local belonging played a defining role $^{31}$. Today as well, it is often argued that local welfare arrangements should be restricted to a state's "own" poor and "deserving" (productive, law-abiding and well-integrated) newcomers only ${ }^{32}$. In some countries, an individual who applies for assistance in a city today must often prove a "connection with the city" and the costs of a newcomer's stay in a city hospital are reclaimed via his or her local insurance fund. Historians have recently demonstrated that although legal regulations regarding access to assistance were increasingly nationalized from the nineteenth century onwards, discussions and decisions about newcomers' entitlements to care remained largely in local hands and continued to be shaped to a large extent by local perceptions of belonging and deservingness. Local bonds often remained the most important argument for inclusion and the granting of relief ${ }^{33}$.

Second, recent studies on practices of migration control in the nineteenth and twentieth centuries have stressed that local authorities and local police forces retained a crucial role despite increasing (inter)nationalization of migration legislation and controls $^{34}$. Scholars have emphasized the "impuissances bureaucratiques" that kept the emerging nation-states from effectively implementing national regulations such as passport controls throughout the long nineteenth century ${ }^{35}$. Others have concluded that most nineteenth-century governments in Western Europe simply made no serious efforts to enforce the law. As "watchman states" with few interventionist ambitions, they introduced migration laws not in order actually to control mobility but for other, partly symbolic, reasons: to create an impression of control and to convince the "dangerous classes" they were subject to strict surveillance ${ }^{36}$.

From the turn of the twentieth century onwards, bureaucratic mechanisms designed to monitor migrants expanded further and nation-states tightened their grip on their population and territory. Still, this did not alter the fact that the enforcement of most national laws and regulations and the everyday surveillance of mobile populations was de facto the task of local police forces. Both municipal police and gendarmes

\footnotetext{
30 Lucassen (2012).

31 Sachße and Tennstedt (1998); Bolender (2007); King and Winter (2013).

32 Melossi (2015).

33 Snell (2006); King and Winter (2013); Schepers (2014).

34 Even in the Habsburg Monarchy and the Republic of Austria, often associated with ever increasing centralism, remarkable continuity can be observed in the shared governance of migration by the state and local actors: Becker (2010).

35 Noiriel (1991, p.58-61).

36 Schrover (2008, p.16); Lucassen (2012).
} 
were involved in regulating passports and residence permits, stationing watches at city entry points, arresting and removing vagrants and beggars, and conducting intense observation of the "dangerous classes". The practices of these local enforcers or "street-level bureaucrats" often differed from national policy goals because of resource issues, the diverging priorities of local commanders, unexpected events on the ground and individual decisions or police discretion ${ }^{37}$. At the same time, the new bureaucratic controls gave local officials sweeping powers, allowing them to impose their own agendas. As Andreas Fahrmeier has concluded on the basis of several case studies in Europe and the United States from the French Revolution to the Inter-War Period:

From the point of view of the police, most of the aims laid down in immigration regulations, e.g. keeping foreigners from entering certain professions, from engaging in political activity, or from embarking on dubious business ventures, could all be resolved by issuing expulsion orders or by refusing to extend residence permits $^{38}$.

Local governments - especially those in states with a long tradition of municipal autonomy such as the German, Belgian and Dutch city mayors and councils - also managed to bend national rules and to tailor their enforcement to local needs and concerns. Tensions between cities and states did not always mean outright opposition, however: central authorities were often glad to leave much of the paperwork, the costs and the frustrations involved in migration control to the care of their local counterparts ${ }^{39}$.

\section{Children and female migrants}

Not all people on the move receive(d) the same treatment in Europe and the United States. Scholars have for some time differentiated between attitudes towards different types of migrants: high-skilled labourers are preferred over low-skilled migrants; members of the European Union have less difficulty crossing borders than those who originate from the "third world", and so on $^{40}$. The same goes for the criminalization of migrant populations: different groups or profiles are subjected to different regimes of control and punishment ${ }^{41}$. Today, crimmigration studies pay particular attention to female migrants and child refugees as "at-risk" groups: this has to do with concerns about human trafficking and the idea that women and children on the move are somehow a "new" phenomenon ${ }^{42}$.

Yet it was in the second half of the nineteenth century that the first major wave of "feminized migration" occurred in Europe, making female migration anything but a marginal phenomenon ${ }^{43}$. Youths also experienced a significant increase in geographical mobility towards the end of the century, which went hand in hand

\footnotetext{
De Koster and Reinke (2016); Lawrence (2011); Gaume (2017).

38 Fahrmeier (2005, p.305).

39 Fahrmeier (2005); Lucassen (2012).

40 Brubaker (1992); Bosworth (2014).

${ }^{41}$ Melossi (2015).

42 Schrover (2013).

43 Schrover (2008; 2013); Greefs and Winter (2016).
} 
with moral panics over White Slavery focusing on unaccompanied young girls as particularly vulnerable. A crucial feature of these concerns about the possible victimization of females and youngsters on the move is that they were coupled with anxieties about the threats posed by "masterless" young men and "loose" girl migrants, who were viewed as extremely prone to illegality and crime - the boys ending up as thieves, the girls as prostitutes. All across Europe and North America, child protection laws proliferated in the early twentieth century, imposing juvenile vagrancy regulations and extra controls on the movements of young people "for their own good". In most cases, such "protective" measures amounted to little more than locking them up in closed state institutions ${ }^{44}$.

In summary, recent research has made clear that both the lived experience of migration and crime and also practices of migration control and criminalization are deeply gendered and shaped by age-differences ${ }^{45}$ Furthermore, there are remarkable similarities between nineteenth-century and contemporary concerns and responses to female and/or young migrants. Today, the protection of the individual rights of unaccompanied young refugees is stressed more than ever, yet the "solutions" that are privileged still mainly consist of locking up illegal migrant children, youngsters and mothers in closed detention centres ${ }^{46}$.

\section{Migrants and the criminal justice system}

This final point returns to the longstanding criminological and sociological question of the differential treatment of migrant populations by the police and the courts. How and why, for example, do travelling groups such as Roma and members of ethnic and religious minorities experience targeted harassment and abuse from police officers and discriminatory sentencing ${ }^{47}$ ? The conference "Ethnicity, Crime and Justice. Contemporary and Historical Perspectives" held in the UK in 2010 and new work on early modern and modern Europe and the United States testify of the growing interest of historians in the subject. A number of scholars have produced interesting new insights which provide a welcome supplement to the existing sociological and criminological research on ethnicity, crime and justice produced from the 1960s onwards ${ }^{48}$. Two issues in particular are worth brief exposition below.

First, although historical and criminological research have amply documented occurrences of racism, discrimination and violence by judicial authorities against newcomers and minorities with a migration background in both contemporary and historical contexts, there is only limited evidence of systematic bias against specific groups of immigrants by the police and the courts. Sometimes different studies even come to contradictory results. The conclusion here is, of course, not that ethnicity, religion or cultural differences do not matter, but rather that they do not explain everything. Scholars such as Peter King, John Carter Wood and Mary Bosworth have recently called to bring "class" back in view, calling for an examination of the

\footnotetext{
44 De Koster (2018).

45 Reinecke (2008). See also the article on "Gender and Crime" by Manon van der Heijden in this issue.

46 Bhui (2013); Bosworth (2014).

47 Bowling and Philips (2003); De Koster and Reinke (2016).

48 King (2016); King and Wood (2015); Sacks (2005); Blanchard (2011).
} 
ways in which the policing and the punishment of migrants underpin and endorse a racialized, gendered and a class hierarchy ${ }^{49}$.

Second, in order fully to comprehend the experiences of migrants in the criminal justice system, one must also ask the question of how these groups ended up before the police and the courts in the first place. Although it is has been established by criminologists and historians alike that most offences and offenders that reach the criminal justice system are not police-detected but victim-reported, this process of "criminalization from the bottom-up" remains relatively under-researched compared to the activity of the police and the courts. Several studies suggest that, in this process, a cluster of factors including public visibility, mobility, the lacking of social bonds, and being perceived as "unattached outsider", plays a crucial role. In different periods and regions, these characteristics acted to reduce migrants" and newcomers' access to informal networks and conflict settlement, and thereby increased their chances of being officially accused and brought before the police and the courts ${ }^{50}$.

\section{POSTSCRIPT: SOME POINTS FOR THE AGENDA OF FUTURE HISTORICALLY INFORMED RESEARCH ON THE "MIGRATION-AS/AND-CRIME"-COMPLEX}

\section{People moving in vs. people moving out}

Although it is to be expected, and logical, that future research will continue to focus on immigration as central to the "migration-as/and-crime"-complex, policies aimed at keeping people from moving out are certainly not obsolete and will perhaps increase in significance once more. As migratory movements will probably increase even further in the future, certain cities and states will need to develop strategies to keep people from moving out. This issue might, therefore, contribute significantly to the core narratives of current crimmigation research.

\section{Bringing the local back in}

The notions of interconnectivity, interaction and conflict between the local, the regional, the state, the (ex-)colony and the metropole, should become core issues on historians' future research agendas, using the concept and perspective of the "glocal" developed by global history. The focus of current crimmigration research on the national and international level leaves important questions untouched, such as, for example, local definitions of belonging and bottom-up criminalization of migrants.

\section{Children and female migrants}

In many current studies, children and women are an appendix only, perceived mostly as objects and/or victims. Seeing them as active subjects, however, drawing on concepts from social history and historical anthropology such as Eigensinn, would draw children and women out of their "niche" of research and of public concern.

49 King (2016); King and Wood (2015); Bosworth (2014).

50 Lis and Soly (1993); Coy (2008); De Koster (2018). 


\section{Migrants and the criminal justice system}

Given the complexity of this issue and the contested and contradictory conclusions of available studies, additional research on the treatment of migrants by the police and the courts is urgently needed. Additionally, long-term research on practices of criminalization of migrants from the bottom-up also deserve a spot on the agenda of further historical crimmigration research.

Margo De Koster Vrije Universiteit Brussel, Belgium \& Vrije Universiteit Amsterdam, The Netherlands margo.de.koster@vub.be

Herbert Reinke Senior Researcher Humboldt Universität, Berlin herbert.reinke@gmail.com

\section{BIBLIOGRAPHY}

Aas, K.F. (2011) Crimmigrant bodies and bona fide travelers: surveillance, citizenship and global governance, Theoretical Criminology, 15, p.331-346.

Adam, I., Ben Mohamed, N., Kagné, B., Martiniello, M. and Rea, A. (2002) Histoires sanspapiers, Brussels: Éd. Vista.

Bade, K.J., Emmer, P.C., Lucassen, L. and Oltmer, J., Eds. (2011) The Encyclopedia of Migration and Minorities in Europe. From the 17th Century to the Present, Cambridge: Cambridge University Press.

Becker, P. (2010) Governance of Migration in the Habsburg Monarchy and the Republic of Austria, in Arnold, P.E. (Ed.), National Approaches to the Administration of International Migration, Amsterdam, Berlin, Tokyo, Washington, DC: IOS Press, p.32-52.

Beier, A.L. and Ocobock, P. (Eds.) (2008) Cast Out: Vagrancy and Homelessness in Global and Historical Perspective, Athens: Ohio University Press.

Berlière, J.M. and Lévy, R. (2011) Histoire des polices en France de l'Ancien Régime à nos jours, Paris: Nouveau Monde Éditions.

Bhui, H.S. (2013) The Changing Approach to Child Detention and Its Implications for Immigration Detention in the UK, Prison Service Journal, 205, p.23-28.

Blanchard, E. (2011) La police parisienne et les Algériens (1944-1962), Paris: Nouveau Monde Éditions.

Bolender, M. (2007) Metamorphosen des liberalen Regierungsdenken: Politische Ökonomie, Polizei und Pauperismus, Weilerwist: Velbrück.

Bosworth, M. (2014) Inside Immigration Detention, Oxford: Oxford University Press.

Bowling, B. and Phillips, C. (2003) Policing Ethnic Minority Communities, in Newburn, T. (Ed.), Handbook of Policing, Devon, UK: Willan Publishing, p.528-555.

Brubaker, R. (1992) Citizenship and Nationhood in France and Germany, Cambridge, MA/ London: Harvard University Press. 
Caestecker, F. (2001) Alien Policy in Belgium, 1840-1940. The Creation of Guest Workers, Refugees and Illegal Aliens, New York/Oxford: Berghahn Books.

Caplan, J. and Torpey, J. (Eds.) (2001) Documenting Individual Identity. The Development of State Practices in the Modern World, Princeton,Oxford: Princeton University Press.

Castles S. (2002) Migration and community formation under conditions of globalization, International Migration Review, 4, p.1143-1168.

Collomp, C. (1996) Regard sur les politiques de l'immigration. Le marché du travail en France et aux États-Unis (1880-1930), Annales. Histoires, Sciences Sociales, 51, 5, p.1107-1135.

Coy, J. (2008) Strangers and Misfits: Banishment, Social Control, and Authority in Early Modern Germany, Leiden: Brill Publishers.

De Koster, M. (2018) Girls' Journeys to the Juvenile Court, Antwerp, 1912-1933, in Trepanier, J. and Rousseaux, X. (Eds.), Youth and Justice in Western States, 1815-1950. From Punishment to Welfare, New York: Palgrave Macmillan, p.279-310.

De Koster, M. and Reinke, H. (2016) Policing Minorities, in Johansen, A. and Knepper, P. (Eds.), The Oxford Handbook of the History of Crime and Criminal Justice, New York: Oxford University Press, p.268-284.

De Munck, B. and Winter, A. (Eds.) (2012) Gates communities? Regulating migration in early modern cities, Aldershot: Ashgate.

Deutsches Historisches Museum (Ed.) (2005) Zuwanderungsland Deutschland. Migrationen 1500-2005, Wolfratshausen: Minerva.

Dohse, K. F. (1985) Ausländische Arbeiter und bürgerlicher Staat. Genese und Funktion von Staatlicher Ausländerpolitik und Ausländerrecht, Berlin: Express Edition.

Dornel, L. (2004) La France hostile: socio-histoire de la xénophobie (1870-1914), Paris: Hachette.

Emsley, C. (2007) Crime, Police and Penal Policy: European Experiences, 1750- 1940, Oxford: Oxford University Press.

Fahrmeier, A. (2005) Law and Practice. Problems in Researching the History of Migration Controls, in Fahrmeier, A., Faron, O. and Weil, P. (Eds.), Migration Control in the North Atlantic World: The Evolution of State Practices in Europe and the United States from the French Revolution to the Inter-War Period. Oxford/New York: Berghahn Books, p.301-316.

Gaume, P. (2017) Le vagabondage, ou la police des existences irrégulières et incertaines: sens et usages d'un délit (France, 1815-1850), Crime, History \& Societies/Crime, Histoire \& Sociétés, 21, 1, p.79-100.

Greefs, H. and Winter, A. (2016) Alone and Far from Home. Gender and Migration Trajectories of Single Foreign Newcomers to Antwerp, 1850-1880, Journal of Urban History, 42, 1, p.61-80.

Huysmans, J. (2006) The Politics of Insecurity. Fear, Migration and Asylum in the EU, London: Routledge.

King, P. (2016) Communities, the Police and the Courts in Late Eighteenth and Early Nineteenthcentury London, Crime, Histoire \& Sociétés/Crime, History \& Societies, 20, 1, p.79-100.

King, S. and Winter, A. (2013) Migration, Settlement and Belonging in Europe, 1500-1930s: Comparative Perspectives, Oxford, New York: Berghahn Books.

King, P. and Wood, J. C. (2015) Black people and the criminal justice system: prejudice and practice in later eighteenth- and early nineteenth-century London, Historical Research, 88, 239, p.100-124. 
Kubal, A. (2014) Struggles against subjection. Implications of criminalization of migration for migrants' everyday lives in Europe, Crime, Law and Social Change, 62, 2, p.91-111.

Lawrence, P. (2011) The Police and Vagrants in France and England During the Nineteenth Century, in Antonielli, L., Polizia, ordine pubblico e crimine tra città e campagna: un confronto comparative. Stato, esercito controllo del territorio, Manelli: Rubbettino, p.49-60.

Leerkes, A., Engbersen, G. and Leun, J. (2012) Crime among irregular immigrants and the influence of internal border control, Crime, Law and Social Change, 58, p.15-38.

Lis, C. and Soly, H. (1993) Neighbourhood Social Change in West European Cities, International Review of Social History, 38, p.1-30.

Lucassen, L. (2012) Cities, States and Migration Control in Western Europe: Comparing Then and Now, in De Munck, B. and Winter, A. (Eds), Gated Communities? Regulating Migration in Early Modern Cities, Aldershot: Ashgate, p.217-240.

Marxen, K. and Werle, G. (2002) Gewalttaten an der deutsch-deutschen Grenze, Berlin: De Gruyter.

Melossi, D. (2015) Crime, Punishment and Migration, London: Sage.

Nagels, C. and Rea, A. (2010) De la criminalisation des travailleurs sans-papiers, Champ pénal/Penal field, VII, [Online], http://journals.openedition.org/champpenal/7865; DOI: 10.4000/champpenal.7865

Ness, I. (Ed.) (2013) The encyclopedia of global human migration, Chichester: Wiley-Blackwell.

Noiriel, G. (1991) La tyrannie du national. Le droit d'asile en Europe 1793-1993, Paris: Calmann-Lévy.

Poynting, S., Noble, G., Tabar, B. and Collins, J. (2004) Bin Laden in the Suburbs: Criminalising the Arab Other, Sydney: Institute of Criminology Series.

Pratt, A. and Valverde, M. (2002) From deserving victims to "masters of confusion": redefining refugees in the 1990s, The Canadian Journal of Sociology/Cahiers canadiens de sociologie, 27, p.135-161.

Reinecke, C. (2008) Policing Foreign Men and Women: Gendered Patterns of Expulsion and Migration Control in Germany, 1880-1914, in Schrover, M., Van Der Leun, J., Lucassen, L. and Quispel, C. (Eds.), Illegal Migration and Gender in a Global and Historical Perspective, Amsterdam, Amsterdam University Press, p.57-81.

Sachße, Ch. and Tennstedt, F. (1998) Geschichte der Armenfürsorge in Deutschland. Vom Spätmittelalter bis zum Ersten Weltkrieg, Stuttgart: W. Kohlhammer.

Sacks, M.S. (2005) To Show Who was in Charge. Police Repression of New York City's Black Population at the Turn of the Twentieth Century, Journal of Urban History, 31, 6, p.799-819.

Schepers, M. (2014) (Post-) Colonial Membership Regimes: Congolese Immigration in Belgium, unpublished paper presented at the ESSHC 2014, Vienna.

Schrover, M. (2013) Feminization and Problematization of Migration: Europe in the Nineteenth and Twentieth centuries, in Hoerder, D. and Kaur, A. (Eds.), Proletarian and Gendered Mass Migrations. A Global Perspective on Continuities and Discontinuities from the 19th to the 21st Centuries, Leiden, Boston: Brill, p.103-131.

Schrover, M., Van Der Leun, J., Lucassen, L. and Quispel, C. (Eds.) (2008) Illegal Migration and Gender in Global and Historical Perspective, IMISCOE Research, Amsterdam University Press.

Snell, K.D.M. (2006) Parish and Belonging. Community, Identity and Welfare in England and Wales, 1700-1950, Cambridge: Cambridge University Press. 
Trautmann, S. (2002) Migration, Kriminalität und Strafrecht. Zur Rolle des Strafrechts im Kontext nationaler Zuwanderungsregelungen - ein Vergleich zwischen Deutschland und Frankreich, Münster: Lit Verlag.

Viet, V. (2002) Histoire des Français venus d'ailleurs de 1850 à nos jours, Paris: Perrin.

Walter, M. (1989) Ausländerkriminalität. Gestern- heute- morgen, in Bundeskriminalamt, Ausländerkriminalität in der Bundesrepublik Deutschland, Wiesbaden: Bundeskriminalamt, p.63-81.

Winter, A. and Lambrecht, T. (2013) Migration, Poor Relief and Local Autonomy: Settlement Policies in England and the Southern Low Countries in the Eighteenth Century, Past and Present, 218, 1, p.91-126. 